\title{
The fiction of History: recalling the past and imagining the future with Caesar at Troy
}

\author{
Richard Alston \\ University of London \\ England
}

\begin{abstract}
This essay considers the nature of historical discourse through a consideration of the historical narrative of Lucan's Pharsalia. The focus is on the manner in which Lucan depicts history as capable of being fictionalised, especially through the operation of political power. The discourses of history make a historical account, but those discourses are not, in Lucan's view, true, but are fictionalised. The key study comes from Caesar at Troy, when Lucan explores the idea of a site (and history) which cannot be understood, but which nevertheless can be employed in a representation of the past. Yet, Lucan also alludes to a 'true history', which is unrepresentable in his account of Pharsalus, and beyond the scope of the human mind. Lucan's true history can be read against Benjamin and Tacitus. Lucan offers a framework of history that has the potential to be post-Roman (in that it envisages a world in which there is no Rome), and one in which escapes the frames of cultural memory, both in its fictionalisation and in the dependence of Roman imperial memory on cultural trauma. KEYwords. Troy; Lucan; Tacitus; Caesar; Germanicus; ruin; historiography; trauma.
\end{abstract}

We are accustomed to honouring the generic difference between history and fiction. Such honouring is reflected in the academic division of labour, between the scholar of literature and the scholar of history, though, of course, our interests often cross. History is and was supposedly true or at least verisimilitude is and was a primary duty of the historian. For the poet, however, the rules of truth are rather different. Yet, neither in modern popular culture nor in antiquity is the division robust. The ease with which ancient historians invented dialogues, the almost complete absence of citations of evidence, and the deploying of psychological insights which would seem to require an intimate knowledge of their subjects exemplify literary techniques that we might more naturally associate with the novelist than with the historian. Furthermore, Roman epic poetry frequently engages

Email: R.Alston@rhul.ac.uk

Professor of Roman History, Royal Holloway. 
with the historical, not only with the remote and mythical history of the age of heroes, but with history that is relatively well-attested and even contemporary, as we see in the poetic imaginings of the Second Punic War, the desire of Cicero to have an epic composed on his consulship, and the seeming pressures placed on Augustan poets to sing of a grander theme and produce the epic of Augustan history. Lucan's Pharsalia exemplifies the potential of the historical narrative to make the transition across the generic divide between history and fiction. In modern cultural production, such transitions are, of course, familiar. The past is for us, as it was for the Romans, too important to be left to historians, and the multiplicity of genres in which the past is discussed represents an engagement and a concern with the past as a central element within contemporary culture. In what follows, I explore the importance of the past in modern and Roman society, and the meaning of the genre-traversal of the past in Roman literary culture. I point to the totalitarian potential of historical narratives in generating a uniform view of the historical experience and suggest that the emergence of Rome as a potentially totalitarian state is predicated on the uniformity of historical narrative. Nevertheless, such uniformity was not achieved, as we shall see. Lucan undermines narrative uniformity and the translation of the past into different generic forms opens a capacity for resistance.

The familiar and trite observation runs that each generation rewrites its past according to its needs and requirements. Yet, the problem is not so much to observe the tendency for historiographical reinvention as to explain it. After all, in a discipline that justifies itself on its claims to truth, the ephemeral nature of those truths is a cause for some concern. The remoulding of the past is not, it seems to me, a result of the endless motility of past time. The past was real and must be understood as such. Yet, the way we understand the past shifts as we rethink and reshaped our understanding of the contemporary world. Further, our desire for rules which will illuminate a better understanding of the ways in which society work (ancient or modern), we come to ask different questions of the past, think about the past in different ways, and explore our relationship to that past from new perspectives. Each generation feels a need to recycle the past since the past is an area of dispute and argumentation in which the nature of current society is explored. ${ }^{1}$

Furthermore, the rewriting of the past is an act of power. The discourses of history are not evanescent. Social formations have historical forms (be they the relationship between men and women, between social 
class, or between nations) which become normalised over time. The past can operate as a means of trapping us into various kinds of social behaviours, which are regarded as norms or inevitabilities. The disciplines of historical analysis tend to preserve narratives of the past as authoritative, reinforcing the social meanings and theories embedded in those interpretations. Yet, each generation needs to rewrite its histories to exercise some control over the past that moulds the society in which they live, and in so doing, histories become controversial, both in the relationship to histories of past generation, in the construction of present meanings, and in the reimagining of the past. But it follows that not only can each generation seek to reimagine its past, but each coherent social group that can find itself defined or, indeed, ignored in the past narratives. Histories from the political edges (post-colonial histories), histories of the poor, and the marginalised, of women (feminist histories), of slaves, of the ethnically cleansed, assert a presence in the contemporary world and a place in the past. History is an ethical issue, and a contentious area. ${ }^{2}$

Only in an ultra-rationalist totalitarian universe will we achieve consensus over the present and its meanings; thus debate about the past should not or cannot come to an end, for such a consensus would enable such a totalitarian present. When there are no questions, no doubts, no arguments about past and present, the writing of history will have its end. Historical writing generates collective memory, a memory that then is adopted within society and which can give societies their necessary sense of identity. Yet, for cultural memory to be effective in establishing social and cultural norms, it needs to translate itself from the social to the individual. The totalitarian potential of historical narrative lies in the possibility of the singular narrative of identity that affects the social being, generating the human in accord with that singular narrative. If the historian renders still the unquiet souls of the dead, to give them their definitive and authoritative place in the narratives of the past (as Michelet would have us believe), history becomes itself authoritative and oppressive. ${ }^{3}$ Fukayama's confident and subsequently retracted predictions of the end of history would represent an end of politics and an end of debate, and, in its Nietzschean form, an end of humanity. ${ }^{4}$ Being human is to be disputatious, and to struggle against

\footnotetext{
${ }^{2}$ There is an industry of studies in cultural memory, see notably, Maurice Halbwachs, The Collective Memory, transl. Francis J. Ditter and Vida Yadzi Ditter, New York, Harper and Row, 1980.

${ }^{3}$ Michel de Certeau, The Writing of History, transl. Tom Conley, New York, Columbia University Press, 1988.

${ }^{4}$ Francis Funuyama, The End of History and the Last Man, New York, Perennial, 2002.
} 
a particular ordering of society in which the individual has a particular place. The End of History can only come in a heavenly Utopia and given that our experience with utopian societies is so traumatic, the heavenly utopia is most likely to come into being through the deployment of vast totalitarian power. A real End of History arises only with the Last Man and in that achievement of that end there is also death. If the historian's goal is to establish the one true narrative of the past, then we have to question the ethical task of the historian.

Paul Ricoeur has argued that operational memory (how we understand how to tie our shoelaces without perpetually having to think about it) and recollection (the conscious calling forth of an imago of the past) are fundamentally related and that there is only a limited difference between cultural memory and personal memory. ${ }^{5}$ Further, since memory is expressed and frequently recalled in language ( narrated), memory is in itself social. Narration enables memory to be sustained, affirmed, and given meaning and by contrast a memory that is not or cannot be narrated becomes a memory which is out of time and out of meaning. Memory, for Ricoeur, needs to be sustained within a social environment through repetition and approbation. The implication of such a socialisation of memory is radical since memory is both fundamental to our very being (we remember who we are) and how we interact socially (we remember how to be with other people). If we remember who we are, but that memory is social, then the social is built deep into our personalities. For Ricoeur, the division between the social and the psychological is, in itself, artificial. Such a close link between the social and the personal ties Ricoeur to radical psychologists, Deleuze and Guattari, for whom the self is constructed in a social environment. Deleuze and Guattari are engaged in an anti-Oedipus, denying the universality of Freudian constructions of the self in society in favour of a more directly embedded social self. ${ }^{6}$ For Freud, the relationship between the self and family was always in contention and although anthropologies may differ between societies, the fundamental tension between an organised society and family and the drives of the individual would persist across time.? The critique of such a position underpins Foucault's analysis of the historical self. ${ }^{8}$

${ }^{5}$ Paul Ricoeur, History, Memory, Forgetting, transl. Kathleen Blamey and David Pellauer, Chicago, Chicago University Press, 2004.

${ }^{6}$ G. Deleuze, F. Guatarri, Anti-Oedipus: Capitalism and Schizophrenia, transl. R.Hurley, M. Seem, and H. R. Lane, London, Athlone, 1984.

${ }^{7}$ R.H. Armstrong, A Compulsion for Antiquity: Freud and the Ancient World, Ithaca and London, Cornell University Press, 2005.

${ }^{8}$ M. Foucault, The Care of the Self: The History of Sexuality III, London, Penguin, 1986. 
Lacan's Freudianism, however, views the psyche as partitioned into orders, between the order of the Symbolic (which is a predominantly social field) and the orders of the Imaginary and the Real. ${ }^{9}$ The fundamental tenet of the Talking Cure is that we can process issues and problems in the Imaginary and the Real only through the Symbolic, but, of course, the entry of a dream or a memory into the Symbolic of language and discourse risks the distortion or transformation of memories. Further a narrated or partially narrated memory influences the original recollection and experience so that the truth of memory may lie at some distance from the memory as narrated. Memories which are not narrated ( memories that are given no existence in the Symbolic) must remain in the Real, where the incomprehensibility of the memory render it as a dream. Furthermore, the non-narrated memory cannot become a cultural memory. There is, therefore, a lack in the identification of the dream-memory in the various realms that parallels the lack in the identification of the self in Lacanian psychoanalysis, and such a lack entails a dissatisfaction with narratives of memory that is essentially and fundamentally related to the dissatisfaction with identity-formation as noted by Sartre among others..$^{10}$

The distance between the narration of memory and the memory that subsists in the psyche, most obviously present in the narrations and memories of horror, offers a potential point of resistance. Such memories can have a bodily visceral form: 'If you cannot smell it, you were not there'. But in the corporeal form of memory, memory becomes unrepresentable (part of the Real). Yet, the memory of horror reaches powerful into the development of collective memory and politicised memory, which can persist with great power in the memory of a collective (a memory of slavery; a memory of the holocaust). Political memory, even foundational memory, that depends on trauma rests on a profoundly Real experience that is not easily translated into the Symbolic. Such memories are most obviously fictionalised since the true horror of the event cannot be recalled. The memory thus resists any attempt at assimilation into a broad political discourse of meaning and is always capable of reasserting its unique experience in denial of the generalities that are required in the development of social memory ('if you cannot smell it, you were not there').

\footnotetext{
9 J. Lacan, Four Fundamental Concepts of Psychoanalysis: The Seminar of Jacques Lacan. XI, transl. Alan Sheridan, New York and London, Norton, 1981

${ }^{10}$ Slavoj ŽIžEK, The Ticklish Subject. The Absent Centre of Political Ontology, London, Verso, 1999; Jean-Paul Sartre, Being and Nothingness: An Essay on Phenomenological Ontology, London, Penguin, 1958.
} 
This corporeal experience of memory connects two other seemingly remotely related aspects of the experience of memory. The first is that memory is pervasive. We remember how we tie our shoelaces, but also how to walk and talk, how to move in the street, and how to interact with others in the community. It is written into the way in which we hold our bodies, into gender relations, and into all elements of our physicality. These regularities of social behaviour are plainly learnt, and, as Pierre Bourdieu has shown, plainly inscribed in our environments. ${ }^{11}$ The environment operates as a mnemonic in which the habitus is continuously reinforced and transmitted. Memory is built firmly into our identities, but identities are also embedded in locations.

Shifting location opens the possibility of identity (and memory) being remade, and in that movement there is an image or a fantasy of freedom, since one might not be confined by the social memories of one's place. Yet, that possibility of a new creation merely acknowledges the differences between symbol-laden environments since if one changes location, one encounters new places and new values, and a new habitus, and in that habitus, there is a place for the outsider. Jacques Rancière has argued that freedom or the democratic moment cannot be accomplished in conventional places, and has looked for places with exists outside conventions. ${ }^{12}$ We could understand these places as those few elements in the spatial world not inscribed with the mnemonics of society. ${ }^{13}$ Such separation could only be achieved in the marginal places, among the ruins, in the places-in-between, in atopia not utopia, or beyond the fringe of imperial power.

Yet, one may doubt whether such places really exist, since places that are in the margins are precisely defined by that marginality, as if merely distance from metropolitan culture creates freedom. Rancière risks romanticising the places without signs that he can read, and turning them into places of freedom, as European colonialists found their freedom in lands which were, according to them at least, unmarked by signs, the cities of the Orient and Africa, Ottoman Greece, the 'unpopulated' and newly discovered lands of Australia, Africa, and the pre-Columbian Americas. One of Ranciere's key examples is the military camps of the mutinies of AD 14, places which might seem exotic in Rome-centred readings, but which were overwhelmed

\footnotetext{
${ }^{11}$ Pierre Bourdieu, In Other Words: Essays towards a Reflexive Sociology, transl. Loic J.D. Wacquant, Oxford, Polity Press, 1990.

${ }^{12}$ J. RANCIÈre, The Names of History: On the Poetics of knowledge, transl. Hassan Melehy, Minneapolis, University of Minnesota Press, 1994.

${ }^{13}$ See also M. AugÉ, Non-Places: Introduction to an anthropology of supermodernity, London, Verso, 1995.
} 
with symbols and history. Making such places free of signs requires an act of power in not reading those signs, which, as we shall see, happens with Caesar in Troy. These willed signless spaces allow scope for the fantasy of the ahistorical man, who can transcend history and establish an ultimate truth. But an awareness of the mutability of signs and the prevalence of such signs, even if we choose not to read them, permits a place to subsist even in a city razed to the ground in which signs persist only and wholly in the memory. Completely new places can be made, but only as fantasies of megalomania.

Place is an issue of memory, but it also has a longer-term historical aspect, since place carries within it memories of events where one was not, cultural memories that are necessary tools for establishing a social identity and a sense of self in the world. These memories are, of necessity, experienced through narration and are equally necessarily incomplete and partial and recognisably so. Every guidebook transmits only a limited experience of a place. The recognition of the partial nature of particular narratives of place and time offers a possibility of alternative constructions and that possibility establishes a difference or distance between societal narratives of cultural memory and what memory could be. Since we can imagine different memories, we can recognise the imaginary in memory.

Lucan's narrative exposes such an imaginary. The Pharsalia blurs the distinction between history and fiction. In so doing, it undermines the foundational narratives of the imperial age as one possible imaginary. The poem follows dramatic convention in imagining being present at the event, but then points to different narrative possibilities including official histories of the event, which are rendered artificial in comparison with Lucan's invented narrative. Further, he hints at the impossibility and unethical nature of a complete history.

Lucan's destabilisation of historical narratives rests partly on horror. It has long been recognised that Lucan's account of the civil war is bloody and visceral. Shadhi Bartsch, in a landmark study, identified the detailed somatic violence of the Pharsalia with a social dissolution, in which the boundaries of the self were sundered in a metaphor for the dissolution of the state. ${ }^{14}$ The Republic was written on the body and destroyed with the body. The spilling of the body is abject, a darkened mirror of the sublime, which exists beyond explanation and reason and in denial of the social; man is ultimately meat in Lucan. The violence of the account, which echoes the techniques of modern war films to emphasise the bloodiness and corporeal-

${ }^{14}$ Shadhi Bartsch, Ideology in Cold Blood. A Reading of Lucan's Civil War, Cambridge, MA and London, Harvard University Press, 1997. 
ity of combat, precisely in the cause of realism, makes the literary spectacle into an experience that is more real, both in the common meaning of the term and in the Lacanian sense of being beyond narrative and explanation. The corporeal nature of the narrative points to a writing of history in bodies and on bodies and the visceral nature of an event which those absent cannot capture or remember, except through the narratives of fiction. Yet, if this is a fictional truth of war, so the historian's memory is exposed as being a different, less real truth. Further, the horror of the war creates a visceral reaction: one is there in the blood and guts of battle that reduces the participants to flesh, a dissolution that destroys the social self, and ultimately society. Instead of reading from the dissolution of society to the dissolution of bodies, as Bartsch does, one can read from the dissolution of bodies to the dissolution of societies. In such blood, no ideology can make sense and a lack of meaningful narrative memory is exposed.

There are a variety of points in the Pharsalia when this gap between the physicality of experience and the narratives of history are exposed. One may think of the matrona at the end of Book 1 (673-695) whose experience of the civil war in a physically traumatic vision cannot be narrated to the shocked crowds and similarly of the priestess of Apollo, Phemenoe, in Book 5 , whose prophecy cannot be translated by the Roman general. Phemenoe's frail and all too human body is seized by Apollo and she is killed by history: Venit aetas omnis in unam/Congeriem, miserumque premunt tot saecula pectus, "All time came as one and so many ages pressed the wretched heart" (Lucan, Pharsalia, 5.177-8). Phemenoe's experience of all history parallels Benjamin's Angel of history, pushed backwards through time and viewing the past in its unified horror. Narrative fails in the face of the bodily and deadly experience of total history which only angels and gods can survive. History itself is fundamentally unknowable and beyond representation. ${ }^{15}$

The narratives of history are exposed not as false, but as incomplete. No representation can capture a meaning and horror that is beyond an assimilation into collective memory. Such a particularity of individual memories and narratives allows a layering of possible narratives in the historical record, as if each narrative is a trace of a particular event and the event itself can be known only through its limited surviving traces. For instance, the narrative of the wars between Marius and Sulla in Book 2 (70-233) is explicitly a narrative of the elders and a cultural memory. That memory is not false, and certainly not short of horror nor of violence, but the presump-

${ }^{15}$ Walter Benjamin, 'Theses on the Philosophy of History', in Illuminations, ed. Hannah Arendt, transl. Harry Zorn. London: Pimlico, 1999, p. 245-55. 
tion that Caesar's war was the same is overlaid by the Pharsalia's metanarrative of revolutionary, unprecedented change that brought into being a new world. Similarly, Caesar's own narrative of the civil wars, delivered before the battle of Pharsalus (7.250-329) is not exactly inaccurate, it is just a version of history that we cannot recognise in the Pharsalia itself. Ominously, Caesar himself remarks: Haec, fato quae teste probet, quis iustius arma/Sumpserit, "Now, fate will bear witness who bears arms with greater justice" (Lucan, Pharsalia, 7. 259-60), suggesting that history will be remade in the aftermath of a battle in which justice will inevitably triumph. The traces of the event that survive will attest to Caesar's righteousness, but the very mention of the possibility of fabricating history points to a negative dialectic in which the alternative traces of the event survive, a spectral presence to haunt the Caesarian narratives of the event. Multiple possible and incomplete narratives co-exist.My key episode comes after the battle of Pharsalia with Caesar's visit to Troy. This story is told out of time. We already know of Pompey's flight, his decision to trust himself to Ptolemy of Egypt, and Ptolemy's treachery; we know that Pompey's son has fled West, and we have been with Cato and his soldiers in their catastrophic and brutal march through the Africa desert, and it is only then that we return to Caesar, making his way slowly from the battlefield in his search for Pompey (9.950-952).

Caesar enjoys a tour of Greece that culminates in Troy (9.964-999). But Caesar is a poor archaeologist. He searches for the walls of Apollo and finds that

Silvae steriles et putres robore trunci

Assaraci pressere domos et templa deorum

Iam lassa radice tenet, ac tota teguntur

Pergama dumetis: etiam periere ruinae.

(Lucan, Pharsalia, 9. 965-969)

sterile woods and rotten tree-trunks lie upon the home of Assarcus and the temples of the gods are now held down by old roots and thorns cover all Pergamon: even the ruins have perished.

Nullum est sine nomine saxum (v.973), 'No stone is without a story', but Caesar, who sees the various sites of memory, is unable to recognise those stories.

Inscius in sicco serpentem pulvere rivum

Transierat qui Xanthus erat. Securus in alto

Gramine ponebat gressus: Phryx incola manes

Hectoreos calcare vetat. Discussa iacebant 
Saxa nec ullius faciem servantia sacri:

'Herceas' monstrator ait 'non respicis aras?'

(Lucan, Pharsalia 9.974-979)

Unknowing, he crossed a stream snaking through the dry dust, which was the Xanthus. Confidently, he stepped through the high grass. The native guide forbade him from stepping on the bones of Hector. When scattered stones, bearing no sign of sanctity lay before him, the guide asked 'Do you not respect the Hercean altar?'

Caesar's tour is unseeing of place, and thus memory would seem closed off to him and in that closure of memory there is an allusion to mortality. Death claims everything, even Troy. Ironically, Lucan reassures Caesar: Pharsalia nostra/Vivet et a nullo tenebris damnabimur aevo, "Our Pharsalia will live and no age will condemn it to the shades" (Lucan, Pharsalia, 9. 985-6). If Lucan is confident, so is Caesar. His nonreading of the city's ruins leaves him unshaken, inscius but securus. He raises an altar to the gods and declares himself gentis Iuleae vestris clarissimus (995) (most famed of the Iulian line), descendant of Aeneas. He promises a Roman Troy (999), and departs.

This is an epic moment and a referential crux. Not only are Caesar and Lucan referencing Homeric Troy and the Iliad, but we are clearly with the Aeneid. As Caesar stands on Hector's bones, so the poetic archaeology gives us Aeneas, and alongside Aeneas we see Augustus (another claimant to be most famous Julian and one whose absence from the Trojan narrative and history undermines Caesar's narrative). Yet, Lucan in the preface has also established an association between Caesar and Nero as the logical outcome of the terrible events which are narrated in the poem. Furthermore, as we shall see later, the visit of Caesar was imitated by Germanicus. The layering of poets and imperial figures is matched by a layering of place, for in the visit to Troy we see not only Troy as it is, but as it was. We see also Rome in an echo of Aeneas's tour of the future site of the city. We may read Caesar's promise to build a Roman Pergamon both as a literal promise to rebuild the Trojan city and as a figurative promise of Rome as the new Troy. Yet, in that association is a far darker note in which the future Rome lies dead, a Rome condemned to the shades.

Lucan has, of course, denied that this is the fate that will befall Rome, but the claim is undercut. If the poetry of Homer is such to have a promise of the immortality of Troy, the disappearance of the city gives a different perspective on urban mortality. Homer has not saved Troy. The memories of Troy are covered in thorns and even the trees that grow over the site have 
rotted. The Trojan inheritance is death and sterility, but is a Trojan inheritance that Caesar himself proclaims and sets out to restore. The meaning of Troy for Caesar and for those who are to receive his message is Caesar himself, the most famous son of the city, not death. Yet, in the destruction that surrounds Caesar, death is ever-present.

Lucan's promise that the empire without limits in space and time will survive rests on unfirm ground. Pharsalia is, notably, 'our Pharsalia', that of the poet and Caesar. Caesar's and Rome's claim to immortality rests on a supreme act of violence and destruction. Pharsalus was, though, also an act of foundation. Pharsalia is thus ours in another way, since it comes to belong to all Romans, and to be the foundational memory of the imperial age, a memory of trauma to set against the memory of imperial foundation that we find in the Aeneid, and in this reading of Roman history and poetry, we are directed to think more of the destruction of Troy in Aeneid's Book 2 rather than the foundation of the Roman people in Latium at the Aeneid's conflicted culmination. Rome and Troy, destruction and construction are thus paired in a complex dialectic in which the cities can neither escape their foundations nor avoid destruction.

If the Pharsalia is the foundational tragedy, Pharsalus becomes the destructive moment of foundation. We are directed to Lucan's account of the battle itself, an account which is, in Lucan's description unspeakable and already condemned to the shades.

Hanc fuge, mens, partem belli tenebrisque relinque,

Nullaque tantorum discat me vate malorum,

Quam multum bellis liceat civilibus aetas.

A potius pereant lacrimae pereantque querellae,

Quidquid in hac acie gessisti, Roma, tacebo.

(Lucan, Pharsalia, 7.552-556)

Flee this, mind, and leave this part of the war in shadow; forbid me from teaching of such great evils and no age will learn how much was permitted in the civil wars. Let our tears fall and our laments be without record: Rome, whatever you did in this battle, I will be silent.

Later, Lucan feels the shame of following and recounting the deaths of individuals in funere mundi (617) and later still that: Mors nulla querella/Digna sua est nullosque hominum lugere vacamus, "No death is worthy of its lament; we have no space to mourn any man" (Lucan, Pharsalia 7.630-1), since Mors hic gentis erat (this death was of a people) (635). Lucan does nevertheless respond to the challenge set by the battle 
by employing many of the tropes of epic battle narration, including the use of the individual narrative. He is also hardly reluctant to fill the lines of the poem with blood and horror. Yet, he has established the unrepresentable nature of the battle, and in so doing renders his own narrative unreliable. The traumatic memories that are written on the individual bodies of the soldiers and into the collective memory of Romans are beyond representation and narratives of the battle, either Caesarian or Lucanic, are necessarily partial. Furthermore, Lucan argues, the death of the nation should not be represented.

Lucan's failed fiction of history undermines Caesar's narrative of Troy. For Caesar, the narrative that he asserts is a narrative of cultural continuity in the history of the Roman people. The fall of Troy and its subsequent disappearance is temporary, for Troy can be seen and reconstructed by Caesar and Troy finds life in its most famous descendant, Caesar. But there are other voices. The description of the site makes it into a place not of life and of continuity, but of death and rot. The destruction of the city is so absolute that even the ruins do not survive as remembrances of what the city was: the walls themselves, constructed by the gods, have gone. In this complete destruction, even divine builders find that their work is impermanent. A further voice comes with the unnamed local guide; it is the guide who has knowledge of the site, and it is the guide who has the temerity to challenge the imperial might of Caesar. But if Caesar cannot see the altars and has no understanding of the site, and is oblivious of the cultural memory and traditions represented by the guide, Caesar remains confident and secure in his ability to represent Trojan history. The reconstruction of Troy that Caesar plans is a denial of the fact of Troy's destruction and of the history of the site that the guide lays before him. Imperial power has the ability to remake Troy and remake history in so doing. Yet, as with the Pharsalia, turning the events into a story of imperial or Roman continuity ignores the unrepresentable and thus uncontrollable memory of death. An empire without end, which no age shall doom to the shades, as promised by Lucan at the end of the visit to Troy is boldly contrasted with a Troy and a Roman people already with the shades.

The issues raised in the fictional narrative of Caesar's visit to Troy recur in Tacitus, Annales and the historical tour of Germanicus. The tour begins the account of AD 18 with Tiberius consul in Rome and Germanicus consul at Nikopolis. At Nikopolis,

igitur paucos dies insumpsit reficiendae classi; simul sinus Actiaca victoria inclutos et sacratas ab Augusto manubias castraque Antonii 
cum recordatione maiorum suorum adiit. namque ei, ut memoravi, avunculus Augustus, avus Antonius erant, magnaque illic imago tristium laetorumque. (Tacitus, Annales 2.53)

he spent a few days refitting the fleet, and at the same time visited the gulf famous for the Actian victory. He viewed the war booty dedicated by Augustus and the camp of Antony, with the remembrances of his ancestors, since, as I have said, Augustus was his great uncle and Antony his grandfather, and this great vision was of sadness and happiness.

Germanicus went on to Athens, sailed across the Aegean, pausing for the birth of Julia, and igitur adito Ilio quaeque ibi varietate fortunae et nostri origine veneranda, "then he came to Troy and there saw the fickleness of fortune and the venerability of our origins" (Tacitus, Annales 2.54). At his next stop, Claros, he may have received omens of his death.

The following year found Germanicus touring the historical sites of Egypt, and there he learnt from the records, as translated by an elderly priest, of the 700,000 military aged men of the Egyptian empire (2.60).

Germanicus's tour of the East is a prelude to his death, explicitly mentioned in the oracle at Claros, a death that will dominate the next books of the Annales. But if Caesar was an imperfect interpreter of the past, Germanicus is aware of the ambiguities of historical memory. This is already clear at Nikopolis, when Germanicus visits the victory monument of Augustus. Tacitus does not tell us the monument was where Octavian had pitched his camp nor that it was decorated with the prows salvaged from Antony's fleet, perhaps because this was general knowledge. Germanicus took the trouble to descend from hill, cross the straits and enter Antony's camp to view the war from there. The recordatio is of both sides of his family, his imago is of victory and defeat, happiness and sadness, and he rejects the univocal view of the historical event represented in the Augustan monument.

We find a similar pattern when Germanicus reaches Troy. Again, the account is brief and it unclear whether we have Germanicus's reading of the site or that of Tacitus, but the reading is not that of Lucan's Caesar. Germanicus is alongside Aeneas and Augustus in viewing the venerable origins of the Roman people, but the varietas fortunae continues the pervasive ambivalence of Germanicus's historical adventure. As with Lucan, the six-word experience of Troy is of catastrophic fall as well as imperial foundation. In Egypt, Germanicus gets to experience a history in which he has no obvious part. The relative absence of Roman markers of memory is reflected in Germanicus forgetting that Egypt was, in fact, closed to Romans of senatorial status, a legacy of his remembered grandfather. In Alexandria, 
he walked the streets in Greek dress (2.59), which recalled the great Republican hero Scipio in Sicily, but this was a visit and a fashion critiqued by Tiberius. Germanicus could not behave as the great Republican hero, and certainly could not forget his place in an imperial system which had been founded by the defeat of his grandfather. The other history experienced by Germanicus in Egypt was of imperial decline and fall. The great armies of Ramses and the tributes paid from the Eastern empire were recalled, but were notable in their absence, and the great monuments of the Pharaohs' empire were in ruins (2.60-61).

Germanicus in the Annales is a character trapped in a very particular set of circumstances. His position within the Julio-Claudian family established him as a centre of opposition to Tiberius, an opposition that continued beyond his death and led to the destruction of his family. In spite of his refusal to oppose Tiberius and his death-bed advice to his wife to put aside her anger for fear of Tiberius (2.72), he is driven into the position of his grandfather, Antony. He can recall the Actian war from Antony's camp; his visit to Alexandria must recall that same grandfather's long association with the city. Germanicus always has the potential to become Antony, but he is both Caesar and Antony. He also walks alongside Aeneas and Caesar and in this combination of Caesarian characters has with him his son Gaius and his grandson, Nero. The imago that Germanicus recalls in these visits is obviously a collective memory since it is a memory that he cannot share, not having been there, but it is, for him of all people, a formative memory, for it is the memory of his ancestors and of the foundation of the imperial position to which he is bound. Germanicus cannot escape that history anymore than he could deny his own identity.

Tacitus is not an obviously philosophical historian and we do not have many musings on the nature of history. His general statement on the practical and moral purpose of the Annales - praecipuum munus annalium reor ne virtutes sileantur utque pravis dictis factisque ex posteritate et infamia metus sit, "I think the first duty of the annals is that virtues are not silenced and that evil words and deeds will fear posterity and infamy" (Tacitus, Annales 3.65) - leads into a more general concern about the nature of the times in which virtues were not easily expressed. It is in book 4, as a prelude to the trial of Cremutius Cordus, that Tacitus expresses his views more fully on the history of the age. In 4.32-33, Tacitus apologises for the persistent gloom of his history, but excuses himself on the grounds that he is accurately reflecting his time and that his history teaches people how to behave under a monarchy. Tacitus is writing a history for the imperial age, and he proclaims that the histories of the Republic were now, thrilling though they 
may have been, of no utility. The implication is that the moral certainties of Republican history no longer applied and this perspective is carried into the speech of Cordus, whose primary crime seems to have been writing in praise of Brutus and Cassius, and describing Cassius as the ultimum Romanorum (4.34). Cordus's suicide is an act of self-association with Brutus and Cassius, and yet it is an exemplum of the imperial age that Cordus was remembered and re-read, since the imperial attempt to ban his writings ensured their popularity (4.35).

Tacitus argues that each age generates its own narrative and seeks the break-point in the historical narrative between Republic and Empire. In Cordus's reading the latter age could be described as being post-Roman. The Cordus episode points to the possibility of different narrative arcs within the historical account. The age of empire has a beginning and in Tacitus has a distinctive form. Germanicus's experience at Actium was of the death of an age, with the defeat of his grandfather, and of the birth of an age, with the victory of his great uncle. Notably, however, that division in history could not be made absolute, for Germanicus himself remained both in the Antonian camp and with Augustus, and later could engage in the pretence of being like Scipio, while being the imperial visitor. Cordus could declare Cassius the last Roman, but seek his place alongside him in historical memory. But as with Lucan's Caesar at Troy, there is yet a further historical arc in which Germanicus experiences the venerable origins of Rome's foundation, an experience which paints Roman history as a continuity from its mythical origins to the present and acknowledges the fickleness of fortune both in the ruination of Troy and, more particularly, the destruction of empire in Egypt.

If there is a paradox of imperial time, it rests within that promulgation of the immortal continuity of Rome. Tiberius's insulting cry in Annales 2.65, 'o homines ad servitutem paratos', follows on from Tacitus's attribution of such behaviour to the nature of the age. Tiberius seems unable to accept the transformations of character and behaviour which were integral to imperial power. The imperial view, that which is represented in the narrative arc traced from Troy to the Caesarian empire, is of a history in which, obviously, there is change, but a history in which the rhythms of events repeat over time, so that the imperial age is merely another episode in Rome's long history. That view can also be seen in the representation of Caesar as another Marius in the popular response to on-coming civil war in the Pharsalia. Yet, that view is rejected by Lucan. For he and Caesar will always have their Pharsalus, terrible and beyond representation, the moment when a people died and in the trauma of which a new age began. Tacitus and Lucan, then, appear to share a conception of the imperial age as fundamentally different 
from the Republic and in the mid to late first century, such views may be less controversial than in the first decades of the Principate.

Within these accounts, however, there are more unsettling perceptions. In the first instance, both Lucan and Tacitus expose the differing arcs of historical narrative that co-exist and in so doing undermine the truth-value of particular historical narratives. If, as Zerubavel argues -

Being social presupposes the ability to experience things that happened to groups to which we belong long before we even joined them as if they were part of our own personal past... acquiring a group's memories and thereby identifying with its collective past is part of a process of acquiring any social identity. ${ }^{16}$

- then a foundational memory that is constructed in a self-generating trauma has implications for the settled nature of that society: the society must always persist in its memory of Pharsalus for the political system to function. In this sense the irremediable characteristic of the imperial system is grotesque and alienating violence, violence that operates to deny the social in making meat of humanity. Further, those narratives of social memory are exposed as not just disputed, but also invented, perhaps held together by political power, but always exposed in the face the unknowable course of history. It would follow that the community whose identity is written into the historical frame is also exposed as artificial, invented, an issue of political power or narrative choice. The narratives remain foundational, but exposed as fictions in the face of the unknowable and unrepresentable nature of history.

The power of Lucan's fiction lies not just in his acknowledgement that the event of foundation is subject to fictionalisations, but that the event itself belongs to the abject, being beyond the powers of description, only to be approached through art. Lucan's ethical silence is not a turning away from the event, but is a refusal to accept the adequacy of description or that a description will ever establish its authority over the event. Pharsalus is an event of a special and traumatic nature, written into and on the bodies of Romans, maintained within memories as trauma. As Badiou has recently been arguing, events of this order cannot be settled successfully into a narrative form, and indeed one needs to return repeatedly to them, not so that the unquiet ghosts of history can be laid to rest and the formative myths and London, Chicago University Press, 2003, p.3. 
of the nation accepted, but precisely to disrupt and unsettle. ${ }^{17}$ In common with much radical thought post-Freud, the aim of talking is not to bring to the subject to rest and acceptance, not to adjust the memories so that there is a an acceptability and meaning to the narrative of trauma, but to use the memories to unsettle consensus. The trauma victim suffers a sense of isolation and of separation from society in that what has happened to him or her cannot be accommodated into the values of society and exposes that society as a fiction. ${ }^{18}$ Lucan's fictional technique returns to the unrepresentable trauma and similarly this gives a perspective on Roman society which is that of the outsider and the alienated.

Yet, there is a further structure of time in Lucan's fiction that also, strangely, persists in the Annales and that is of a pre- and post-Roman age. Since the archaeology of Troy is by implication an archaeology of Rome, the Troy that lies dead before Caesar is by analogy the future as well as the past of Rome. The experience of Troy is of a rise and fall of empires, and that experience is replicated in the demise of the Egyptian empire. Phemenoe's inability to survive the absolute knowledge of time suggests that such time frames are incomprehensible. But if time is unknowable, identities and places become fragile. The very fact that there can be a revolutionary moment in which the nature of historical time is changed leaves open the possibility of further shifts in the historical complex. Such complexes of time are integral to particular socio-political formations, the empire in this example, but the fact of change make it possible to envisage times before or after empire. It becomes possible to imagine a post-Roman future. Such perceptions may be inevitable when individuals become aware of alternative narrative arcs in the framing of history, and thus Scipio wept for Rome as Carthage burnt before him in $146 \mathrm{BC} .^{19}$ The post-Roman future which fleetingly haunts the texts of the Annales and Pharsalia is uncertain, offering other narratives of history that will transform present and past. But the post-Roman future is also threatening.

Lucan's engagement with history is radical. In the violence of the revolutionary course of the Pharsalia an age is destroyed and an age is made. The change is traumatic; the dissolution of bodies that pervades the narra-

\footnotetext{
${ }^{17}$ A. Badiou, Ethics: An Understanding of Evil, transl. Peter Hallward, London, Verso, 2001. A. BADIOU, Handbook of Inaesthetics, transl. Alberto Toscano, Stanford, CA, Stanford University Press, 2005.

${ }^{18}$ SusAn J. BRison, 'Traumatic narratives and the remaking of the self', in M. BAL, J. Crewe, and L. Spitzer, Acts of Memory: Cultural Recall in the Present, Hanover and London, University Press of New England, 1999, p. 39-54.

${ }^{19}$ Appian, Roman History 8.132.
} 
tive tears apart the social fabric in the memory of events which cannot be accommodated within a social order. The myths of imperial foundation are exposed as only one possible reading of the past, and one that fails to accommodate the trauma of Pharsalus. Pharsalus can never be escaped, can never be forgotten, but can never be fully understood or fixed into the narratives of meaning. The imperial narratives of time are supported by great power, by the power of Caesar, but even Caesar's narrative is limited and partial. Within the social narratives in which meaning is granted to society and individuals find their identity is the bloody spectre of the truly non-social human, man as meat. History as a whole is asocial, known and knowable only to the gods. All these forces lurk behind the narratives of history, barely contained in the myths of the age, and behind all those narratives lurks the ultimate spectre of the fall of Troy and Rome in which there is a dissolution of social memory, an end of humanity, and the triumph of death. The postRoman spectre is not a new heroic age of freedom in which heroes such as Germanicus can find their freedom and place, though it certainly would represent an ending of the current and particular formation of space and time, but a pervasive zone of decay and death. Rome and Troy are inextricably linked: death and foundation. Empire's birth is attended by Empire's end.

Título. A fição da História: resgatando o passado e imaginando o futuro com César em Troia

Resumo. Este artigo aborda a natureza do discurso histórico por meio da observação da narrativa histórica da Farsália de Lucano. O foco é a maneira pela qual Lucano apresenta a história como passível de ser ficcionalizada, especialmente por meio da operação do poder político. Os discursos da história geram um relato histórico; porém, na visão de Lucano, tais discursos não são verdadeiros, mas ficcionalizados. A chave do estudo deriva da visita de César a Troia, quando Lucano explora a ideia de um lugar (e uma história) que não pode ser compreendido, mas que ainda assim pode ser utilizado na representação do passado. Por outro lado, Lucano alude a uma 'história verdadeira' que é irrepresentável em seu relato de Farsalos e está além dos limites da mente humana. A história verdadeira de Lucano pode ser lida em confronto com Benjamin e Tácito. Lucano fornece um enquadramento da história que tem o potencial de ser pós-romana (na medida em que concebe um mundo em que Roma não existe), no qual se escapa às estruturas da memória cultural, tanto em sua ficcionalização quanto na dependência da memória imperial romana em relação ao trauma cultural. Palavras-chave. Troia; Lucano; Tácito; César; Germânico; ruínas; historiografia; trauma. 